\title{
On The Importance of Out-Of-Class Language Learning Environments: A Case of a Web-Based E-Portfolio System Enhancing Reading Proficiency
}

\author{
Somayeh Fathali \\ Tohoku University, 41 Kawauchi \\ Aoba Ward, Sendai, Miyagi, Japan \\ somayeh.fathali.p7@dc.tohoku.ac.jp
}

\author{
Takeshi Okada \\ Tohoku University, 41 Kawauchi \\ Aoba Ward, Sendai, Miyagi, Japan \\ takeshi.okada.a8@tohoku.ac.jp
}

\begin{abstract}
This study was conducted to enhance our understanding of the importance of designing out-of-class language learning (OCLL) environments as one of the indispensable modes of the blended learning environments. Quantitative and qualitative data was obtained from 212 Japanese EFL non-English major undergraduate students. Through a pretest-posttest controlled group design we investigated the effect of a webbased e-portfolio system developed for the OCLL context, which in this case specifically aimed to improve the learners' reading proficiency. The comparison of TOEFL ITP ${ }^{\circledR}$ pretest and post-test scores indicated the significant difference between the performance of the experimental group and the comparison group learners. Two focus group interviews during the term and end of the term semi-structured interviews with the experimental group learners examined the effectiveness of the web-based e-portfolio system as a means for OCLL. The findings and implications are discussed.
\end{abstract}

Keywords: blended learning environments, out-of-class language learning, web-based e-portfolio, reading proficiency

\section{INTRODUCTION}

The recent ICT (information and communication technology) supported learning/teaching contexts have made language teachers put a greater stress on the importance of the so-called blended learning environments which successfully combine the traditional classroom activities with the appropriate use of technology. Neumeier (2005) points out that blended learning environments are usually composed of two modes of delivery: face-to-face (F2F) and computer-assisted language learning (CALL). However, the crucial point is that normally these two modes are combined within the class, and there remains a serious demand for effective out-of-class language learning (OCLL) opportunities (Benson, 2001; Borrero \& Yeh, 2010), especially in the EFL learning contexts where learners have very little or no exposure to English beyond the class.

According to Richards (2015: p.1), "there are two important dimensions to successful second language learning: what goes on inside the classroom and what goes on outside of the classroom". Findings from previous studies provide evidence that out-of-class learning has a significant role in language learning process (Lai \& Gu, 2011; Pearson, 2004; Pickard, 1996), and it can enhance learning outcomes in multiple ways (Chang, 2007; Inozu, Sahinkarakas, \& Yumru, 2010; Sundqvist, 2011). Since much of effective learning can happen free of the classroom boundaries through informal learning contexts, learning should not be restricted to the formal classroom contexts (Chatti et al., 2012) and ICT must be employed in a way to support the optimization of both inside and beyond the classroom learning environments (Chapelle, 2010; Zhao \& Lai, 2007).

Furthermore, successful development of the technology-enriched beyond class contexts requires instructors' constant and accurate support (Lai, 2015; Lai, Zhu \& Gong, 2014). There are various kinds of technological tools applicable for OCLL (Lai \& Gu, 2011), yet some may not be as effective and beneficial as others. Accordingly, instructors are expected to introduce or design context-based OCLL modes appropriate to the learners' basic needs and abilities. In this regard, this paper first introduces a web-based e-portfolio system, developed to enhance reading proficiency of Japanese EFL learners through the beyond class reading practice, and then describes the effect of this OCLL 
context on the improvement of the leaners' reading proficiency, through a pretest-posttest controlled group design. Finally, to understand the experimental group learners' attitude towards the affordances and challenges of the system, the findings from the two focus group interviews during the term and semi-structured interviews at the end of the term are discussed.

\section{THE DEVELOPMENT OF THE OCLL CONTEXT}

Benson (2001) refers to out-of-class language learning as autonomous learning achievements accomplished at any time and in any place regardless of the conventional classroom borders. Hall (2009) refers to this beyond class learning as the informal education and he states that informal learning can be empowered by technology to help learners identify themselves in the virtual space and create personalized learning environments. According to Milligan et al. (2006), personalized learning environments such as electronic portfolios can provide control over learning experiences, and connects the beyond conventional learning environments to the formal institutional settings (Barrett, 2006). Reinders (2014) argues that personal learning environments (PLEs) can enhance lifelong learning by going beyond the formal academic environments. He introduces different electronic devices to create PLEs, such as e-portfolios, collaboration tools, planning and monitoring tools, etc. Among all, e-portfolios can keep a holistic continuous record of the learners' language learning development and growth during a certain period of time (Barrett, 2000), and they combine out of class learning achievements with the formal inside class progress (Goldsmith, 2007; Barrett, 2006).

Furthermore, Reinders (2014) discusses further the difference between PLEs and virtual learning environments (VLEs). Although the terms are used across different contexts and sometimes interchangeably, he argues that VLEs are more teacher-supported and institution-focused environments that are mainly used to deliver courses and to act as complements to the PLEs. The efficient integration of VLEs and PLEs can result in transferring learners from VLEs to continue independent learning using their own PLEs. Consequently, in this study we have combined a VLE (website) and PLEs (e-portfolios) by developing a web-based e-portfolio system in order to support learners' independent beyond class reading practice. It is worth mentioning that though the system is designed in a way that can be used to support practicing various language skills and sub-skills only by substituting learning contents, EFL reading proficiency enhancement was the central attention of the present study.

\section{SySTEM DESIGN}

Peachey (2013) emphasizes on the implementation of the open-access web-based tools in online environments to ensure that all learners can access easily and freely. Therefore, the web-based eportfolio system in this study was developed by the effective use of two free and easily available Google applications: Google Drive as the personal learning environments (PLEs) and Google Sites as the collaborative virtual learning environment (VLE). Figure 1 illustrates the homepage of the system's website in which the required components are categorized as the individual pages on the left side of the homepage. Due to the features of Google Sites, the pages are arranged in an alphabetical order. Although the alphabetical order does not accord with the actual procedure, here the pages are explained according to the website's arrangement.

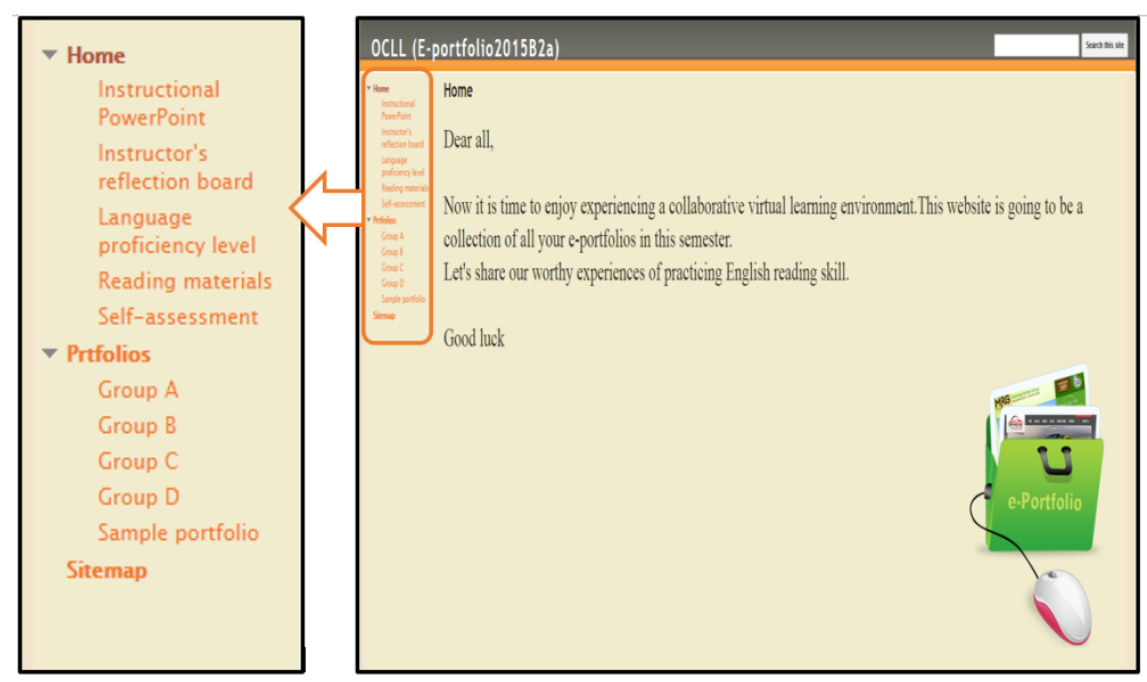

Fig1. Homepage of the OCLL website 


\section{- Instructional PowerPoint}

In order to reach the system's full potential, it is necessary to provide instructional training sessions in advance. The F2F induction sessions can provide the learners with a precise insight of the whole process and can boost their motivation and engagement. To do so, a Microsoft Office PowerPoint file, including an illustrated step-by-step explanation of the whole process was created and presented in the first session. The file was also uploaded on the website for the learners' probable reference afterward.

\section{- Instructor's reflection board}

The second page named instructors' reflection board is an important section to enhance the sense of connectedness between the instructors and the learners (Smith \& Tillema, 2003). The page includes the instructors' constant support through overall weekly feedbacks on the learners' ongoing assignment submissions as well as the crucial points figured out through weekly monitoring of the eportfolios. The instructors tried to investigate common learning obstacles and eliminate them by introducing online supplementary training materials.

\section{- Language proficiency level}

The third page of the website is designed to help the learners find their own English fluency level. A link to the Cambridge English language assessment website (http://www.cambridgeenglish.org/testyour-english/adult-learners/) directs each learner to an online test, of which their final scores are interpreted according to the Common European Framework of Reference for Languages (CEFR). The initial language proficiency test is to provide the learners with an overall grasp of their English skills in order to assist them in finding reading materials appropriate to their levels in autonomous learning environments.

\section{- Reading materials}

The large number of accessible authentic materials on the web simply provide sufficient reading practice opportunities. However, not all the available materials lead to effective and proper learning. Learners need their instructor's constant support and guidance in order not to be misled in the vast virtual environment (Murray, 2005; Kitsantas, 2013). Accordingly, an accurate investigation of online authentic reading materials resulted in some pedagogically and academically approved EFL websites and the links to them are inserted on this page. Due to the large number of the graded reading materials in the selected websites, learners' are able to choose their preferred materials independently based on their initially indicated language proficiency level.

\section{- Self-assessment}

As Alderson (2005) states, self-assessment can lead to self-awareness and indication of a person's weaknesses, strengths, and learning preferences. Consequently, this page concentrates on how learners monitor their own learning outcomes and at the same time set goals to improve their future learning. Being able to set appropriate individual goals can maximize motivation for autonomous learning (Schunk, Pintrich, \& Meece, 2007). Therefore, a set of scoring criteria, based on the objectives of the course was accurately designed to guide the learners in reflecting on their personal achievements and set goals for their future language learning process (Kitsantas, 2013).

\section{- Portfolios}

Uniting all the e-portfolios in a single virtual collaborative space allows the learners to directly observe and grasp how their classmates are learning using distinctive strategies (Kitsantas, 2013), and at the same time enhances peer and expert feedback. The learners not only feel connected to the instructor but more importantly, they must feel that they belong to a 'community' of the learners sharing the same learning goals. As shown in Figure 1, learners are randomly categorized into groups. The number of the groups and the number of the learners in each group depend on the total number of the learners in the class. Each learner has a personal page with his/her full name, and hyperlinked to his/her personal e-portfolio created in Google Drive.

According to the European Language Portfolio (ELP), a portfolio requires three essential sections: a) language passport (any official qualifications, intercultural experiences, and proficiency in different languages defined according to the levels of CEFR); b) language biography (inside and outside classroom learning experiences and individual learning plans through goal-setting and self-assessment 
checklists); and c) dossier (a record of the learner's achievements and works in progress). Hence, in this study, each learner is asked to include the following three types of files in his/her personal eportfolio.

a) An introduction file consisting of the learner's personal language backgrounds and experiences in addition to their intended goals and plans for learning. (To do so, an online introduction form consisting of 19 multiple-choice and open-ended questions is assigned initially to obtain the required information.)

b) Weekly goal setting and self-assessment scoresheets.

c) The collection of the learners' weekly reading files including the links to the reading materials and post-reading activities.

Peachey (2013: p7) argues that "passive reading or viewing materials that require no action, interaction or reflection soon tire online learners and do not lead to deeper engagement or learning". Therefore, an effective way to improve reading achievements is its integration with other skills such as writing through post-reading activities. Post-reading activities, for instance, writing summaries, listing newly learned words, making questions, describing information, having discussions with classmates, etc. can assist the readers to interact actively with the text and boost their learning outcomes (Rivas, 1999). Accordingly, each learner uploaded a weekly file of their reading practice, including the links to the passages they read during the week and their preferred post-reading activities.

In order to facilitate systematic mutual feedback, learners from opposite groups were randomly assigned into pairs for weekly interactions. The learners were instructed on the distinction between self-level (praise) and task-level (correction) feedback (Hattie and Timperley, 2007), and they were asked to practice task-level feedback in their interactions. The task-level feedback was based on Shute's (2008) approach in which there are three types of feedback: 1) Knowledge of results (KR) that only specifies whether the answer is correct or incorrect; 2) Knowledge of correct response (KCR) that indicates the incorrect answer together with the correct response; and 3) Elaborated feedback (EF) that not only provides the correct response but also adds more information such as explaining the correct response, referring to a useful material, etc.

\section{MeThodology}

\subsection{Participants}

The study was conducted in one of the Japanese national universities, and the participants were 212 EFL non-English major undergraduate students attending general English classes. Four classes were randomly chosen for this study, two classes as the experimental group $(\mathrm{N}=109)$ and two classes as the comparison group ( $\mathrm{N}=93)$. Though all the students took part in the classes, three students did not attend either the pre-test or post-test and their scores were removed from the analysis.

\subsection{Research Context}

In the context of the present study, general English classes were held twice a week, each session 90 minutes, and the semester lasted for almost 4 months. The participants practiced reading skill of TOEFL ITP ${ }^{\circledR}$ test in an e-learning environment inside the classroom using an interactive blended English language learning enhancement system (iBELLEs, Okada \& Sakamoto, 2015). The participants of the experimental group continued practicing reading beyond the classroom through the developed web-based e-portfolio system, whereas the learners of the comparison group followed the common beyond class practice guideline in which they were introduced to the list of appropriate language practice websites and asked to continue reading practice outside of the class without any designed OCLL environments.

\subsection{Data Collection and Analysis}

For the quantitative phase of the study, all the learners of both the experimental and the comparison groups took two different samples of TOEFL ITP ${ }^{\circledR}$ test reading section at the beginning (pre-test) and at the end of the semester (post-test). One-sample K-S test was conducted to confirm the normality of distribution of scores. The homogeneity of the participants in terms of reading proficiency in the two groups was checked through an independent samples t-test of the pre-test scores. Finally, an independent samples t-tests compared the means of the gain scores of both experimental and comparison groups. 
The qualitative phase of the study was conducted through two focus group interviews during the semester and end of the term semi-structured interviews with 20 participants selected randomly from the experimental group. All the interviews focused on finding answers to five central issues stated below. The interviews were all recorded and transcribed for content analysis through coding for themes, finding patterns, interpretation of the data and drawing conclusions (Dornyei, 2007). The questions were as below.

1. How do you feel about the e-portfolio system? (Easy/Difficult; Useful/ Useless)

2. Which part of the system did you find the most useful? Why?

3. Which part of the system did you find the most challenging? Why?

4. Which part of the system did you find less useful? Why?

5. Do you like to continue using the e-portfolio system? Why?

\section{Results}

The normality of the distribution of TOEFL ITP ${ }^{\circledR}$ pretest scores was checked through One-sample K-S test and the findings revealed the normality of the distribution of scores in both the experimental $[Z=$ $0.733 ; p=0.300]$ and the comparison group $[Z=0.649 ; p=0.285]$. In order to make sure of the homogeneity of the experimental and the comparison groups before the treatment, an independent samples t-test was conducted to compare the scores of the pre-test. The results indicated that there was no significant difference between the mean scores of both groups [ $t(197)=0.445 ; p=0.657]$, hence, it was concluded that the two groups were homogeneous in terms of their reading proficiency.

After making sure of the normality of distribution of the reading post-test scores using One-sample K$S$ test for the experimental group [ $Z=0.176 ; P=0.137]$ and the comparison group $[Z=0.273 ; P=0.431]$, to explore the probable improvement in the learners' reading proficiency, an independent samples ttest was conducted for their reading gain scores. Table 1 shows the descriptive statistics of the participants' reading pre-test and gain scores in both groups.

The descriptive statistics of the scores indicated that there was a difference between the means of gain scores of the experimental group (8.54) and the comparison group (4.54). Table 2 indicates if this difference was statistically significant.

Table1. The descriptive statistics of reading pre-test and gain scores

\begin{tabular}{|c|c|c|c|c|c|c|}
\hline & & $\mathrm{N}$ & Minimum & Maximum & Mean & Std. Deviation \\
\hline \multirow{2}{*}{$\begin{array}{c}\text { Reading } \\
\text { pre-test }\end{array}$} & Comparison group & 92 & 38 & 94 & 62.00 & 11.88 \\
\cline { 2 - 7 } $\begin{array}{c}\text { Reading gain } \\
\text { scores }\end{array}$ & Experimental group & 107 & 40 & 92 & 62.75 & 11.72 \\
\cline { 2 - 7 } & Comparison group & 92 & -18 & 28 & 4.54 & 9.48 \\
\hline
\end{tabular}

Table2. Independent samples $t$-test for the reading gain scores

\begin{tabular}{|c|c|c|c|c|c|c|c|c|c|c|}
\hline & \multicolumn{2}{|c|}{$\begin{array}{c}\text { Levene's Test } \\
\text { for Equality of } \\
\text { Variances }\end{array}$} & \multicolumn{7}{|c|}{ t-test for Equality of Means } \\
\hline & & \multirow[t]{2}{*}{$\mathrm{F}$} & \multirow[t]{2}{*}{ Sig. } & \multirow[t]{2}{*}{$\mathrm{t}$} & \multirow[t]{2}{*}{$\mathrm{df}$} & \multirow[t]{2}{*}{$\begin{array}{c}\text { Sig. } \\
\text { (2-tailed) }\end{array}$} & \multirow[t]{2}{*}{$\begin{array}{c}\text { Mean } \\
\text { Difference }\end{array}$} & \multirow[t]{2}{*}{$\begin{array}{l}\text { Std. Error } \\
\text { Difference }\end{array}$} & \multicolumn{2}{|c|}{$\begin{array}{c}95 \% \text { Confidence } \\
\text { Interval of the } \\
\text { Difference }\end{array}$} \\
\hline & & & & & & & & & Lower & Upper \\
\hline \multirow[t]{2}{*}{$\begin{array}{c}\text { Gain } \\
\text { scores }\end{array}$} & $\begin{array}{c}\text { Equal } \\
\text { variances } \\
\text { assumed }\end{array}$ & .173 & .678 & 2.55 & 197 & .011 & 3.49 & 1.36 & 0.801 & 6.186 \\
\hline & $\begin{array}{c}\text { Equal } \\
\text { variances } \\
\text { not } \\
\text { assumed }\end{array}$ & & & 2.56 & 196.5 & .011 & 3.49 & 1.36 & 0.805 & 6.181 \\
\hline
\end{tabular}

As can be observed in table 2, based on Levene's test, the equality of variances is assumed $[F=0.173$; $p=0.678]$, and the results suggest that the difference between the gain scores of the experimental and the comparison groups of the study is significant $[t(197)=2.55 ; p<0.05]$. Therefore, it can be concluded that the experimental group significantly outperformed the comparison group in terms of reading proficiency. 
To investigate the results of the second phase of the study which sought the learners' attitude towards the affordances and challenges of the web-based e-portfolio system, all the interviews were recorded, transcribed, read, and analyzed through coding for themes. The common themes for each question were investigated and they are explained in the next section.

\section{Discussion}

This study was conducted to enrich our understanding of the importance of designing out-of-class language learning contexts as one of the indispensable modes of the blended learning environments. Although the use of technology inside the classroom has been effective in improving the quality of learning, restricted learning opportunities in the class highlights the significance of learning beyond the classroom (Chapelle, 2010; Lai, 2015; Zhao \& Lai, 2007). Limited inside class language exposure emphasizes the importance of providing learners with additional teacher-supported learning chances beyond the classroom borders (Barrs, 2012; Richardson, 2010). In line with previous studies (Chang, 2007; Inozu, Sahinkarakas, \& Yumru, 2010; Lai \& Gu, 2011; Pearson, 2004), the findings of this study also suggest the significant influence of a well-organized language practice beyond the classroom. The analysis of the performance of the comparison and the experimental groups reflect the significant improvement of the experimental group learners in their reading proficiency as the result of using the web-based e-portfolio system. The learners of both the comparison and the experimental group were asked to continue practicing beyond the classroom. The comparison group were just provided with the resources whereas the experimental group were provided with a systematic OCLL context. Therefore, as stated by Wittaker (2013) blended learning environments should be developed with the combination of three major modes: F2F, CALL, and self-study mode. And language teachers and instructors need to invest enough time an effort in the design and implementation of appropriate and organized language learning environments beyond the ordinary classroom.

Furthermore, the qualitative phase of the study aimed to investigate the experimental group learners' attitude towards the affordances and challenges of the web-bases e-portfolio system in order to improve its future effectiveness. The learners' answers to the interview questions are discussed below.

\section{How did you feel about the e-portfolio system? (Easy/Difficult; Useful/Useless)}

The learners believed that because of experiencing e-portfolios for the first time and sharing a collaborative space with the rest of the class and the instructors, it was very difficult for them at the beginning. They emphasized the importance of the instructor's guidance in addition to the instructional PowerPoint file since they had referred to the file several times during the first weeks. The learners stated that after some sessions working on the system, they could easily follow the process and found the system very useful for their out of class language practice.

Which part of the system did you find the most useful for language learning? Why?

The results reflect that learners found the reading materials section as the most useful part of the system. They believed having access to the approved EFL websites where they could find authentic materials appropriate to their levels was very useful. They added that not only they benefitted from the reading materials, but they could also practice other language skills such as listening and writing in the specified websites. They also stated that although doing post-reading activities and writing them in their e-portfolios took a lot of time, it could help them keep a record of their achievements and refer to them anytime they wished.

Accordingly, we believe that the findings of this question maximizes the significance of designing OCLL environments. The experimental group learners found the introduced resources very beneficial for their improvement and this is while the comparison group learners were also provided with the same resources, but they did not show significant difference in their advancement compared to those learners in the experimental group. Therefore, we can conclude that the appropriate resources lead to better outcomes if they are offered in a well-developed OCLL environment.

Which part of the system did you find the most challenging? Why?

The analysis of the findings indicates that the learners found peer-commenting as the most challenging part because of two reasons: first, they believed providing weekly comments on the achievements of their counterparts was very time consuming as they had to read through their friends works very carefully. Second, they stated that they did not consider themselves proficient enough to be able to provide appropriate comments on their friends' works and they did not feel comfortable to point out the existing errors since they were not sure about them. 
Which part of the system did you find less useful? Why?

The findings of this question are in close relation with the previous question. The learners argued that they admired their friends' efforts for providing comments on their works, and in many cases they benefitted from their counterparts' feedback. However, they believed it would be more useful if they could individually receive instructor's comments in addition to their peers' comments.

We assume this idea can be related to the Japanese learners' cultural beliefs and educational background. Similar to many Asian learners, Japanese EFL learners are accustomed to the teachercentered learning environments (Hirata, 2010) and peer-supported language learning is not highly valued by the learners. Accordingly, since the large number of the learners in the classes, as we observed in this study, makes it impossible for the instructors to provide comments on the learners' weekly works individually, the promotion of the quality of peer-feedback and the learners' attitude towards peer-feedback is of crucial importance in the OCLL environments. This issue is now under investigation and more scrutiny is being applied to help learners benefit from peer-feedback.

Do you like to continue using the e-portfolio system? Why?

The learners showed interest in continuing their practice through the web-based e-portfolio system because they were satisfied with their accomplishments on TOEFL ITP ${ }^{\circledR}$ test, and they liked having a personal e-portfolio (Google Drive) containing their works during one semester.

\section{CONCLUSION}

This study provides an explanation of the design and implementation of a web-based e-portfolio system to enhance Japanese EFL learners' OCLL. The inadequate duration of classes considering the large number of learners, and lack of effective collaboration outside of the class highlight the necessity of focused and structured self-study modes to ensure complementary language learning opportunities. As mentioned earlier in the EFL contexts, language learners usually lack enough support and materials beyond the formal classrooms, and teachers are required to encourage and support the self-directed use of technology beyond the classroom. Although there are unlimited language learning tools and resources in the modern technological era, the findings indicates that it is not easy for the learners to benefit from the available materials independently. Therefore, it is the instructors' foremost responsibility to guide the learners through the path, so that they become lifelong language learners. Considering the significant effectiveness of the e-portfolio system developed in this study, we hope the findings have implications for language teachers by providing insights into the development of effective OCLL environments through the proper application of technological devices.

\section{REFERENCES}

[1] Alderson, J. C. (2005). Diagnosing foreign language proficiency: the interface between learning and assessment. London: Continuum.

[2] Barrett, H. C. (2000) Create your own electronic portfolio. Learning \& Leading with Technology, 27(7): 14-21.

[3] Barrett, H. C. (2006). Using electronic portfolios for classroom assessment. Connected Newsletter, 13(2): 4-6.

[4] Barrs, K. (2012). Fostering computer-mediated L2 interaction beyond the classroom. Language Learning \& Technology, 16(1): 10-15.

[5] Benson, P. (2001). Teaching and researching autonomy in language learning. Harlow, England: Longman.

[6] Borrero, N. E. \& Yeh, C. J. (2010). Ecological English language learning among ethnic minority youth. Educational Researcher, 39(8): 571-581. doi.org/10.3102/0013189x10389810

[7] Chang, M. (2007). Enhancing web-based language learning through self-monitoring. Journal of Computer Assisted Language Learning, 23(3): 187-196. doi:10.1111/j.1365-2729.2006.00203.x

[8] Chapelle, C. (2010). Evaluating computer technology for language learning. TESL-Ontario, 36 (2): 56-67. 
[9] Chatti, M. A., Agustiawan, M. R., Jarke, M. \& Specht, M. (2012). Toward a personal learning environment framework. In Thomas, M. (ed.), Design, implementation, and evaluation of virtual learning environments. Hershey: Information Science Reference, 20-40. doi:10.4018/978-14666-1770-4.ch003

[10] Council of Europe. (2001). Common European framework of reference for languages: learning, teaching, assessment. Cambridge: Cambridge University Press. http://www.coe.int/en/web/ portfolio/principles-and-guidelines-and-cefr

[11] Dörnyei, Z. (2007). Research methods in applied linguistics: Quantitative, qualitative and mixed methodologies. Oxford: Oxford University Press.

[12] Goldsmith, D. J. (2007). Enhancing learning and assessment through e-portfolios: A collaborative effort in Connecticut. New Directions for Student Services, 119: 31-42. doi:10.1002/ss. 247

[13] Hall, R. (2009). Towards a fusion of formal and informal learning environments: the impact of the read/write web. Electronic Journal of E-Learning, 7(1): 29-40.

[14] Hattie, J., \& Timperley, H. (2007). The power of feedback. Review of Educational Research, 77: 81-112. doi:10.3102/003465430298487

[15] Hirata, Y. (2011). Evaluating web content for self-directed language learning. In Dettori, G. \& Persico, D. (eds.), Fostering self-regulated learning through ICT. New York: Information Science Reference, 79-193.

[16] Inozu, J., Sahinkarakas, S. \& Yumru, H. (2010). The nature of language learning experiences beyond the classroom and its learning outcomes. US-China Foreign Language, 8 (1): 14-21.

[17] Kitsantas, A. (2013). Fostering college students' self-regulated learning with learning technologies. Hellenic Journal of Psychology, 10(3): 235-252.

[18] Lai, C. (2015). Modeling teachers' influence on learners' self-directed use of technology for language learning outside the classroom. Computers \& Education, 82, 74-83. doi:10.1016/ j.compedu.2014.11.005

[19] Lai, C. \& Gu, M. (2011). Self-regulated out-of-class language learning with technology. Computer Assisted Language Learning, 24(4): 317-335. doi:10.1080/09588221.2011.568417

[20] Lai, C., Zhu, W., \& Gong, G. (2014). Understanding the Quality of Out-of-Class English Learning. TESOL Q TESOL Quarterly, 49(2), 278-308. doi:10.1002/tesq.171

[21] Milligan, C. D., Beauvoir, P., Johnson, M. W., Sharples, P., Wilson, S. and Liber, O. (2006). Developing a reference model to describe the personal learning environment. In Scott, E. T. P. (ed.), Innovative approaches for learning and knowledge sharing. Berlin: Springer, 506-511.

[22] Murray, D. E. (2005). Technologies for second language literacy. Annual Review of Applied Linguistics, 25: 188-201. doi:10.1017/s0267190505000103

[23] Neumeier, P. (2005). A closer look at blended learning parameters for designing a blended learning environment for language teaching and learning. ReCALL, 17(02): 163-178. doi:10.1017/s0958344005000224

[24] Okada, T., \& Sakamoto, Y. (2015). Dynamic lesson planning in EFL reading classes through a new e-learning system. In F. Helm, L. Bradley, M. Guarda, \& S. Thouësny (eds), Critical CALL - Proceedings of the 2015 EUROCALL Conference, Padova, Italy, 444-449. doi. org/10.14705/rpnet.2015.000373

[25] Peachey, N. (2013). A blended learning teacher development course for the development of blended learning in English Language Teaching. In Tomlinson B. and Whittaker C. (eds.), Blended learning in English language teaching: Course design and implementation. London: British Council, 65-73.

[26] Pearson, N. (2004). The idiosyncrasies of out-of-class language learning: A study of mainland Chinese students studying English at tertiary level in New Zealand. In Reinders H., Anderson, H., Hobbs, M. and Jones-Parry, J. (eds.), Supporting independent learning in the 21 st century. Paper presented at the inaugural conference of the independent learning association. Melbourne, 121-133.

[27] Pickard, N. (1996). Out-of-class language learning strategies. ELT Journal, 50 (2): 150-159. doi:10.1093/elt/50.2.150 
On The Importance of Out-Of-Class Language Learning Environments: A Case of a Web-Based EPortfolio System Enhancing Reading Proficiency

[28] Reinders, H. (2014). Personal learning environments for supporting out-of-class language learning. English Teaching Forum, 4, 14-19.

[29] Richards, J. C. (2015). The changing face of language learning: Learning beyond the classroom. RELC Journal, 46(1), 5-22.

[30] Richardson, W. (2010). Blogs, wikis, podcasts and other powerful web tools for the classroom. Thousand Oaks: Corwin Press.

[31] Rivas, R. M. M. (1999). Reading in recent ELT course books. ELT journal, 53(1): 12-21. doi:10.1093/elt/53.1.12

[32] Schunk, D., Pintrich, P. and Meece, J. (2007). Motivation in education: Theory, research and applications. New York: The Guilford Press.

[33] Shute, V. J. (2008). Focus on formative feedback. Review of educational research, 78(1): 153189. doi: 10.1002/j.2333-8504.2007.tb02053.x

[34] Smith, K. \& Tillema, H. (2003). Clarifying different types of portfolio use. Assessment \& Evaluation in Higher Education, 28(6): 625-648. doi:10.1080/0260293032000130252

[35] Sundqvist, P. (2011). A possible path to progress: Out-of-school English language learners in Sweden. In Benson, P. and Reinders, H. (eds.), Beyond the language classroom. New York: Palgrave Macmillan, 106-118.

[36] Whittaker, C. (2013). A military blend. In Tomlinson, B. and Whittaker, C. (eds.), Blended learning in English language teaching: Course design and implementation. London: British Council, 175-183.

[37] Zhao, Y. \& Lai, C. (2007). Technology and second language learning: Promises and problems. In Parker, L. L. (ed.), Technology-mediated learning environments for young English learners: Connections in and out of school. Mahwah: Lawrence Erlbaum Associates, 167-205.

\section{AUTHORS' BIOGRAPHY}

Somayeh Fathali, is a PhD student at the Department of Applied Linguistics, Graduate School of International Cultural Studies, Tohoku University, Japan. She received her MA in TEFL and BA in English Literature from Alzahra University, Iran. She is interested in teaching and learning languages in blended learning environments.

Takeshi Okada, is Professor of Applied Linguistics at Graduate School of International Cultural Studies, Tohoku University, Japan. After working on a corpus-based analysis of Japanese-specific English spelling errors at Birkbeck College, University of London, UK, he is now leading a research group of blended e-learning system for Japanese EFL learners. 